\title{
Short case report Mycoplasma in a case of acute arthritis with purpura of suspected genital origin
}

\author{
ELLI JANSSON*, U. VAINIO, A. LASSUS, AND SIRKKA TUURI \\ From the Department of Dermatology and Venereology, University Central Hospital, Helsinki, Finland
}

Carlson, Spector, and Douglas (1951) described two children with prolonged fever, migratory arthritis, purpuric rash, and abdominal pain with loose bloody stools. Mycoplasmas, not serotyped, were isolated from several cultures.

We have recovered a mycoplasma from the bone marrow specimen of two children with acute idiopathic thrombocytopenic purpura (Jansson, Wegelius, and Tuuri, unpublished) and have cultured a mycoplasma from the joint fluid of a man with acute arthritis and purpura. This latter case is presented below.

\section{Methods}

The methods of mycoplasma investigation have been described elsewhere (Jansson, Mäkisara, Vainio, Snellman, and Tuuri, 1971).

\section{Case report}

A man aged 40 years had previously been in good health. On September 13, 1968, his right knee became swollen and painful; these symptoms persisted for about 2 days, and then the left knee and ankle became affected and petechiae appeared on both legs. He was admitted to hospital 5 days later.

\section{Examination}

Blue spots and petechiae were seen on the right arm and on both lower extremities. The ankles and feet were reddish and warm. The body temperature was not raised.

ESR $28 \mathrm{~mm}$./1st hr; White blood cells 7,900 per cu.mm.; Platelets 226,000 per cu.mm.; Haemoglobin 15.9 g. per cent.; Bleeding time $2 \mathrm{~min}$.; Coagulation time $3 \mathrm{~min}$. 40 sec. Proteins were present in the urine specimen and there were 6 to 10 erythrocytes and 8 to 14 leucocytes per ${ }_{6}^{1}$ th field.

The tentative diagnosis was Reiter's disease or gonococcal arthritis, but culture of aspirate from the left knee

Received for publication June 1,1971

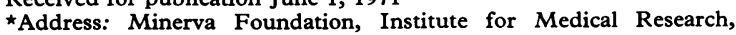
Töölönkatu 12, Helsinki 10, Finland for $N$. gonorrhoeae was negative. Kristensen, Widal, Paul-Bunnell, and antinuclear antibody tests were negative; antistreptolysin-O titre $1: 250$, antistaphylolysin 0.64 units. The bone marrow was normal.

\section{Course}

In hospital the patient's condition became serious; he had migratory pains and swellings in different parts of the body, particularly in the hands and finger joints. Petechiae continued to appear on both upper and lower extremities. The ESR rose to $87 \mathrm{~mm} . / 1 \mathrm{st} \mathrm{hr}$, and the white blood cell count to 12,000 per cu. $\mathrm{mm}$. The haemoglobin fell to $11.5 \mathrm{~g}$. per cent.

\section{Treatment}

He was first treated with procaine penicillin, and when the skin eruptions appeared the antibiotic was changed to tetracycline $2 \mathrm{~g}$. daily, but this seemed to have no effect upon the illness. Urine excretion decreased and creatinine rose to $1.7 \mathrm{~g} . / 24 \mathrm{hrs}$. On October 7 , prednisone $20 \mathrm{mg}$. daily was started, and the patient's subjective condition improved almost immediately. The diastolic blood pressure fell from 120 to $110-105$, and the creatinine value also fell. 5-10 g. protein had been excreted in the urine daily, and this also began to decrease, but there were still erythrocytes in the urine.

A kidney biopsy revealed histological changes compatible with those seen in focal nephritis. On November 11, he went home much improved, but continued to attend the outpatient department for follow up.

\section{Progress}

By April 24, 1969, the ESR was $13 \mathrm{~mm}$./1st hr; urinary erythrocytes 20 to 40 and leucocytes 1 to 3 per $\frac{1}{6}$ th field; protein $2.5 \mathrm{~g}$. daily.

On March 16, 1971, the urine was normal. The ESR was $12 \mathrm{~mm}$./1st hr, haemoglobin $14.8 \mathrm{~g}$. per cent., whiet blood cells 5,800 per cu. mm., antistreptolysin-O titre $1: 400$, antistaphylolysin 4.0 units. The Waaler-Rose, latex, cryoprecipitin tests, and tests for antinuclear antibodies were negative and the cold agglutinins $<4$.

\section{Studies on mycoplasmas}

A mycoplasma, related to $M$. arthritidis had been isolated from the joint fluid in the left knee on admission. By 
the indirect haemagglutination test, antibodies were detected against $M$. arthritidis in a titre of $1: 64$, against his own strain in a titre of $1: 128$, and against an isolate 71-T cultured by us from the urethral specimen of a man with nongonococcal urethritis (NGU) at a titre of 1:128 (Jansson, Lassus, Stubb, and Tuuri, 1971). A second serum specimen taken on March 16, 1971, revealed titres of 16,8 , and 32 , respectively against the three antigens. A T-strain mycoplasma was cultured from the urethral specimen at the same time. The patient's wife was also seen and a vaginal swab revealed a $\mathrm{T}$-strain mycoplasma.

\section{Comment}

The patient's illness was serious enough to require prednisone treatment. This had a beneficial effect, although the disease was of long duration. The clinical symptoms and signs first aroused suspicion of Reiter's disease or gonorrhoea, but the final diagnosis was Schönlein-Henoch purpura.

The antibody findings also indicated that the patient's illness was probably of genital origin. It is noteworthy that he had antibodies against a $\mathrm{T}$-strain mycoplasma from NGU. In a previous study made by us, serological evidence of a recent infection with $\mathrm{T}$-strain mycoplasma was found in 24 per cent. of 54 patients with NGU (Jansson, Lassus, Stubb, and Tuuri, 1971).

A mycoplasma with characteristics similar to those established in this study had previously been isolated from several patients with rheumatoid arthritis (Jansson, Mäkisara, Vainio, Vainio, Snellman, and Tuuri, 1971). Our findings are in accordance with the assumption that in some cases arthritis may be of genital origin.

\section{Summary}

A serious and prolonged illness with migratory arthritis and purpura in a man aged 40 is described.
A mycoplasma related to Mycoplasma arthritidis was isolated from the joint fluid. Antibodies against this species, against a T-strain mycoplasma of urethral origin and against his own strain were detected in the serum.

A T-strain mycoplasma was isolated from the patient's urethra and also from his wife's vaginal secretion.

Our findings indicate that this form of arthritis may sometimes be of genital origin.

This study was supported by a grant from the Sigrid Jusélius Foundation.

\section{References}

Carlson, H. J., Spector, S., and Douglas, H. G. (1951) Amer. F. Dis. Child., 81, 193

Jansson, E., Lassus, A., StubB, S., and TuURI, S. (1971) Brit. F. vener. Dis., 47, 122

-, Mäkisara, P., Vainio, K., Snellman, O., and TUURI, S. (1971) Acta rheum. scand., 17, 227

,,-- , Vainio, U., SNellman, O., and TuURI, S. (1971) Ann. rheum. Dis., 30, 506

-, Wegelius, R., and TUURI, S., Unpublished results

Présence de mycoplasma d'origine génitale possible dans un cas d'arthrite aigue avec purpura

SOMMAIRE

Un cas de maladie sérieuse et prolongée avec arthrite migratoire et purpura est décrit chez un homme de $\mathbf{4 0}$ ans. Un mycoplasme s'apparentant à Mycoplasma arthritidis fut isolé du liquide articulaire. On mit en évidence dans le sérum des anticorps contre cette espèce, contre un mycoplasme souche $\mathrm{T}$ d'origine urétrale et contre la souche considérée.

Un mycoplasme de souche $\mathrm{T}$ fut isolé dans l'urètre du malade ainsi que dans la sécrétion vaginale de sa femme.

Nos recherches indiquent que quelques formes d'arthrites peuvent être d'origine génitale. 